\title{
Antioxidant activity of Phaseolus L. species seeds with different coat colour
}

\section{O. N. Bezuhla,}

\section{V. Pozdniakov,}

L. N. Kobyzeva,

\section{R. L. Boguslavskiy,}

\section{O. V. Antsyferova}

Plant Production Institute named after $V$. Ya. Yuryev, 142 Moskovskyi Avenue, 61060 Kharkiv, Ukraine Email:izhikolga@mail.ru
The aim of the research was to screen the antioxidant activity of mature seeds of related bean species using the collection samples of the National Center for Plant Genetic Resources of Ukraine: Phaseolus vulgaris L., P. multiflorus Lam., P. lunatus L. and P. acutifolius A. Grey which have different colouration of their seed shell. The determination of antioxidant activity was carried out using the improved method of the stable radical DPPH •: methyl alcohol in the eluting solution was replaced by non-toxic ethyl alcohol. The results of the analysis are presented as the equivalent of a standard antioxidant (chlorogenic acid), expressed in $\mathrm{mg}$ of the standard per $1 \mathrm{~g}$ of a sample, taking into account dilutions according to the calibration schedule. As a result of the Phaseolus L. collection screening, it was found that the antioxidant activity of bean seeds depended on the colour of the seed coat. Regardless of the bean type, white seeds had the lowest indicator (equivalent to chlorogenic acid is $0.82-0.96 \mathrm{mg} \mathrm{g}^{-1}$ of seed). Painted seeds have different antioxidant activity. In P. vulgaris L., olive seeds have the highest index (4.21-5.07 mg g-1 of seeds), it is $2.36-3.60 \mathrm{mg} \mathrm{g}^{-1}$ in wine red seeds and $2.72-3.21 \mathrm{mg} \mathrm{g}^{-1}$ in pink ones. And the tendency of the influence of drawing colour and the area of a seed coat is noticed. In P. lunatus L., the antioxidant activity of white seeds with a motley wine-red pattern $\left(2.27 \mathrm{mg} \mathrm{g}^{-1}\right.$ of seeds) is more than twice as high as of white seeds without a pattern $\left(0.94 \mathrm{mg} \mathrm{g}^{-1}\right.$ of seeds). In P. multiflorus Lam., all the coloured seeds had a very high antioxidant activity regardless of the seed coat colour and its pattern $\left(6.09-6.16 \mathrm{mg} \mathrm{g}^{-1}\right.$ of seeds). In P. acutifolius A. Gray, the change in this parameter, depending on the seed coat colour, was small (1.27-1.62 $\mathrm{mg} \mathrm{g}^{-1}$ of seeds). It was found that the antioxidant activity of beans depended on the environmental conditions: the stress of plants because drought leads to its increase.

Keywords: antioxidant activity, Phaseolus vulgaris L., Phaseolus multiflorus Lam., Phaseolus lunatus L., Phaseolus acutifolius A. Grey, colouration of the seed coat

\section{INTRODUCTION}

Contemporary studies (Yashin, Chernousova, 2009; Lin, Tang, 2007; Nijveldt et al., 2001; Duan et al., 2006; Jenkins et al., 2002) showed that antioxidants consumed with plant food helped the person to acquire control over his/her organism and withstand the aggressive influence of the environment: reduced tissue damage, prevented numerous diseases, including infectious ones, and increased life expectancy. Legumes, being powerful sources of phenolic compounds, rank a leading place in terms of antioxidant contents in mature seeds (Tsuda et al., 1993; Onyeneho, Hettiarachchy, 1991). Bean (Phaseolus L.) seeds contain great amounts of phenols, starch, 
vitamins (A, B1, B2, B3, B6, PP), micronutrients $(\mathrm{K}, \mathrm{Mg}, \mathrm{Ca}, \mathrm{P}, \mathrm{Na}, \mathrm{Fe}, \mathrm{I})$ and fructooligosaccharides protecting the body against oxidative stresses, thus preventing cardiovascular and oncological diseases as well as diabetes (Câmara et al., 2013). It was noted that the antioxidant activity in legumes, including bean, varied depending on colouration of the seed coat: it was significantly higher in red and pink seeds than in white ones (Oomah et al., 2010; Nyau et al., 2016).

In this study, collection accessions of related bean species with a wide range of the colour gamut of their seed coat were studied to reveal dependence of the nutritional value of ripened seeds on their colouration. To do this, the goal was to screen the antioxidant activity in ripe seeds of four bean species, Phaseolus vulgaris L., P. multiflorus L., P. lunatus L. and P. acutifolius A. Gray, depending on the seed coat colour.

\section{MATERIALS AND METHODS}

The antioxidant activity (AOA) was determined using the stable radical DPPH $\bullet$ by S. Arabshahi and A. Urooj's (2007) method with the improvement: methanol in an eluting solution was substituted for non-toxic ethanol (Bonoli et al., 2004; Zhou, Yu, 2004). The DPPH concentration was chosen so that the maximum extinction of solutions should not exceed 1.4 units, and the light transmission of all solutions should be within the linear part of the calibration curve. To reduce the effect of temperature fluctuations in the laboratory (from +13 to $+30^{\circ} \mathrm{C}$ ), the reaction time was increased from $30 \mathrm{~min}$ to $2 \mathrm{~h}$ (Poznyakov, Vasylenko, 2017). The analysis data are presented as chlorogenic acid equivalents in $\mathrm{mg}$ of the standard (chlorogenic acid) per $g$ of a sample, adjusted for dilutions according to the calibration curve.

Collection bean accessions of the National Center for Plant Genetic Resources of Ukraine (NCPGRU) with the most common colouration of the seed coat (white, yellow, olive, isabelline, pink, red, brown and black) with or without a pattern were used as the test material: 31 P. vulgaris L. accessions, 5 P. multiflorus Lam. accessions, 6 P. acutifolius A. Gray accessions and 2 P. lunatus L. accessions harvested in 2015-2017. The colouration of the seed coat was determined according to the valid Descriptors List (Bezuhla et al., 2004) in accordance with the colour scale (Bondarev, 1954).

The collection accessions were grown in a special crop rotation on the experimental field of the Plant Production Institute named after V. Ya. Yuryev of NAAS (Elitnoe Village, Kharkiv District, Kharkiv Region, Ukraine - the location $49^{\circ} 59^{\prime} 02^{\prime \prime} \mathrm{N}, 36^{\circ} 27^{\prime} 51^{\prime \prime} \mathrm{E}, 195 \mathrm{~m}$ above the sea level). The soils are represented by chernozem powerful weakly alkaline. The forecrop was winter wheat. Agrotechnics is generally accepted for the Forest-Steppe zone of Ukraine. Sowing was carried out with a manual sowing device, without replications in the optimal timing for beans. The sowing scheme was $30 \times 10 \mathrm{~cm}$ and the accounting area $1 \mathrm{~m}^{2}$. The block of check varieties was placed through each 20 numbers of collection accessions. The evaluation of the collection accessions was carried out in accordance with the existing methodological recommendations for collection samples of legumes (Kobyzeva et al., 2016). The statistical processing of the experimental data was carried out by the dispersion analysis method according to Dospehov (1985). The correlation analysis was carried out using the STATISTICA 6.1, SN BXXR502C631824 NET3.

The years of vegetation of bean plants were characterized by a different ratio of the temperature regime and precipitation: in 2015 the ratio of temperature and moisture approaches the optimal ratio (hydrothermal coefficient HTK was 1.37), 2016 is characterized by waterlogging $(\mathrm{HTK}=1.88)$, and 2017 is characterized by high summer temperatures and a moisture deficit $(\mathrm{HTK}=0.28)$ (Fig. 1).

The determination of the HTK during analysis of the weather conditions of the bean growing season was carried out according to the formula proposed by Selyaninov (1930):

$$
\mathrm{HTK}=\frac{\sum r}{0.1 \times \sum t},
$$

where $\Sigma r$ is the sum of precipitation for the growing season, $\mathrm{mm}$;

$\Sigma t$ is the sum of temperatures above $10^{\circ} \mathrm{C}$ for the same period, ${ }^{\circ} \mathrm{C}$;

0.1 is the coefficient. 


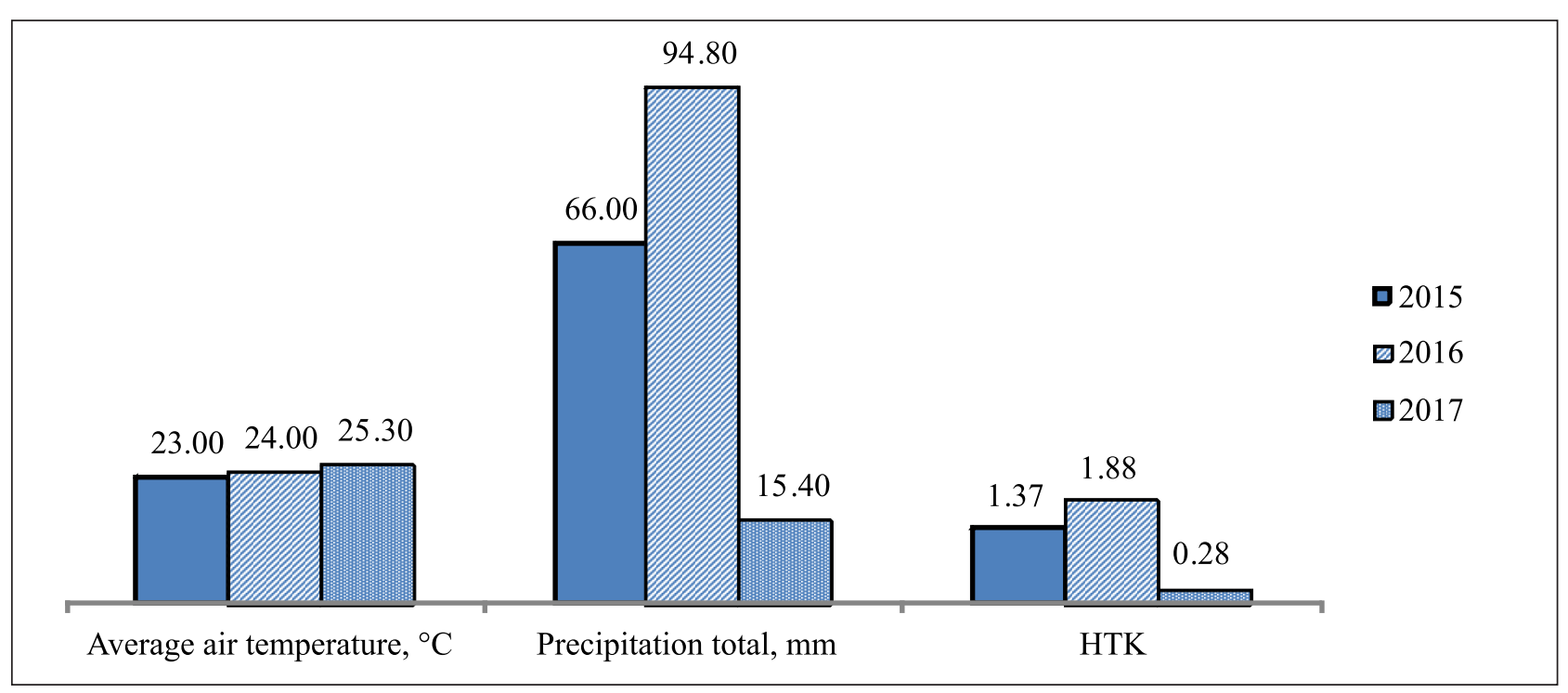

Fig. 1. Characteristics of weather conditions in the vegetation period of beans in the Kharkov Region, 2015-2017

\section{RESULTS AND DISCUSSION}

Legumes are a powerful source of dietary antioxidants. S. A. Marathe et al. (2011) found a high AOA in horse gram, common bean, cowpea (brown and red) and fenugreek. They showed a high DPPH - radical scavenging activity - more than 400 units/g. Lablab bean (cream and white), chickpea (cream and green), butter bean and pea (white and green) showed a low AOA - less than 125 units/g. The intermediate position was occupied by green gram, black gram, pigeon pea, lentils, cowpea (white) and common bean (maroon). Green gram, black gram, pigeon pea, lentils, cowpea (white) and common bean (maroon) showed an intermediate activity. It was proved that not always dark-coloured seeds had a high AOA (e.g. moth bean, black pea, black gram and lentils).

A. N. Maina et al. (2005) investigated dependence of the AOA level on the seed coat colour and its inheritance in Vigna unguiculata (L.) Walp. It was revealed that the accessions with black and red seeds had a high AOA and the beige ones had a low AOA. The factors determining AOA were the same as those responsible for the colour of the seed coat with obvious pleiotropic effects.

V. Nyau et al. (2016) screened bean samples of different seed coat colour which is most common in the Zambian markets. It was found that the AOA level was lowest in white beans, and further in an increasing order were brown, gray variegated and red seeds. The values of FRAP ranged from 1.69 to $6.88 \mathrm{mmol} \mathrm{Fe2+/100} \mathrm{g} \mathrm{DW.}$ A positive linear dependence of AOA on total polyphenols and tannins was found what indicates their effect on the AOA level in bean seeds. Similar conclusions about the positive correlation of total polyphenols and tannins with AOA have been made by other investigators (Beninger, Hosfield, 2003; Pourmorad et al., 2006; Hajimahmoodi et al., 2006).

We found that the AOA in seeds of P. vulgaris L. depended on colouration of the seed coat and varied from $0.82 \mathrm{mg} \mathrm{g}^{-1}$ of seeds (chlorogenic acid equivalents) to $5.07 \mathrm{mg} \mathrm{g}^{-1}$ of seeds. The lowest AOA was recorded in seeds with white seed coats: UD0303351 (0.89 $\mathrm{mg} \mathrm{g}^{-1}$ of seeds), UD0300397 (0.82 $\mathrm{mg} \mathrm{g}^{-1}$ of seeds) and UD0300282 (0.96 $\mathrm{mg} \mathrm{g}^{-1}$ of seeds). This is relevant both to plain seeds and to seeds with a peri-scar spot: UD0303961 (0.82 $\mathrm{mg} \mathrm{g}^{-1}$ of seeds). Yellow seeds (UD0301468 is $0.92 \mathrm{mg} \mathrm{g}^{-1}$ of seeds) were similar to white ones in terms of this parameter (Fig. 2).

The AOA in mestizo seeds, in which half of the seed is white and the other part is vinousred with a variegated pattern, was slightly higher than that in plain white ones. Moreover, the regularity was observed: if a larger part of the seed surface was white, the AOA was lower (UD0303789 - $1.23 \mathrm{mg} \mathrm{g}^{-1}$ of seeds, UD0303687 - $1.24 \mathrm{mg} \mathrm{g}^{-1}$ of seeds) than that in the accessions with a larger vinousred part (UD0301428 - $1.62 \mathrm{mg} \mathrm{g}^{-1}$ of seeds, UD0300693 - $1.58 \mathrm{mg} \mathrm{g}^{-1}$ of seeds). The accessions 


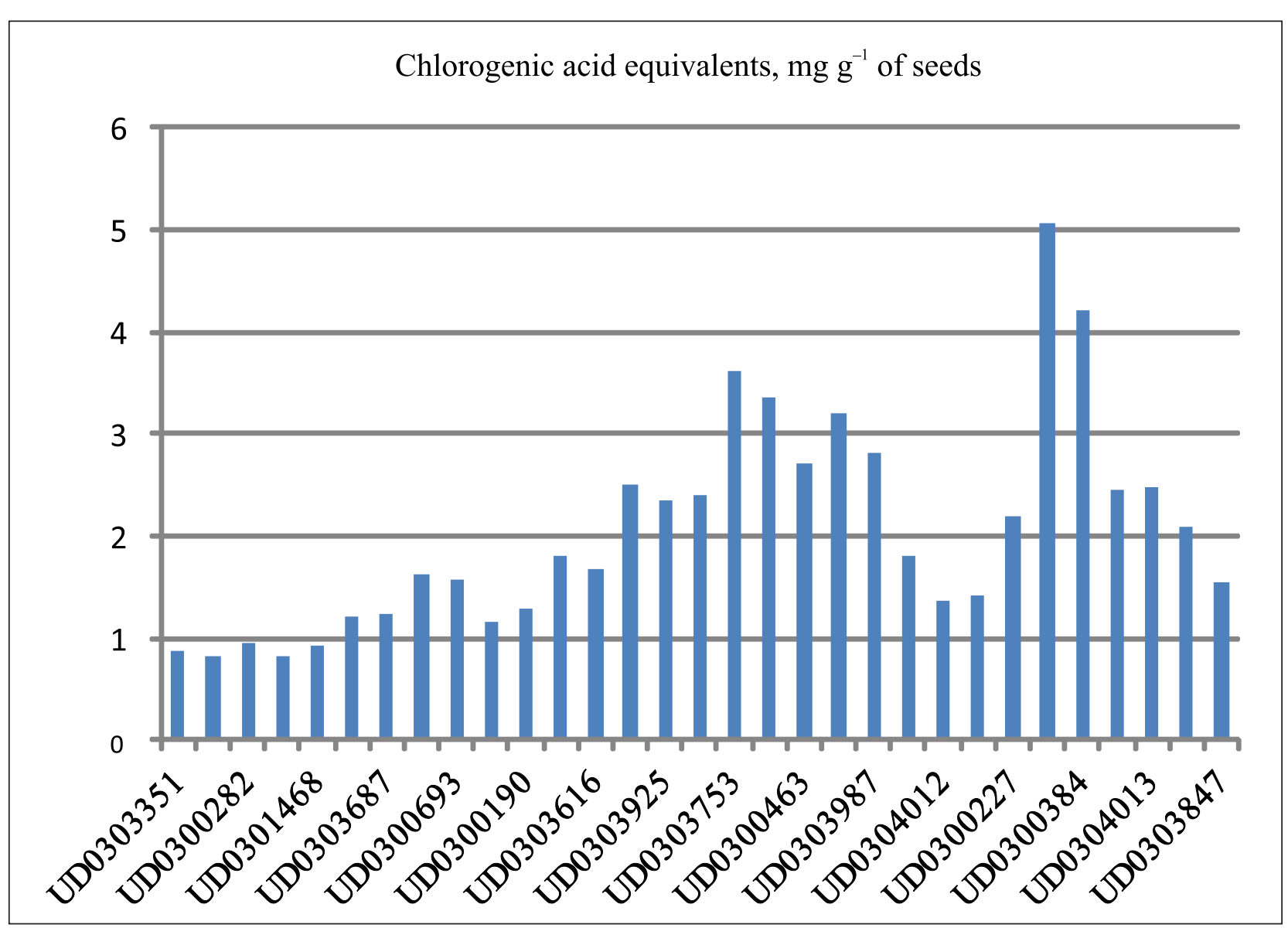

Fig. 2. Changes in the AOA in P. vulgaris L. seeds, depending on the colouration of the seed coat $\left(\mathrm{LSD}_{005}=0.054\right)$, average for 2015-2017

with ocher seed coats (UD0301415 - $1.17 \mathrm{mg} \mathrm{g}^{-1}$ of seeds, UD0300190 - $1.28 \mathrm{mg} \mathrm{g}^{-1}$ of seeds) were comparable to mestizo seeds. Isabelline (UD0304012 - $1.37 \mathrm{mg} \mathrm{\textrm {g } ^ { - 1 }}$ of seeds, UD0301412 - $1.82 \mathrm{mg} \mathrm{g}^{-1}$ of seeds) and brown (UD0303979 - $1.81 \mathrm{mg} \mathrm{g}^{-1}$ of seeds, UD0303616 - $1.68 \mathrm{mg} \mathrm{g}^{-1}$ of seeds) seeds had slightly higher AOA. If there was a pattern on the isabelline seed surface, the AOA depended on the pattern colour: seeds with a black pattern (UD0304011 - $1.42 \mathrm{mg} \mathrm{g}^{-1}$ of seeds) had much lower values than seeds with an olive pattern (UD0300227 - $2.20 \mathrm{mg} \mathrm{g}^{-1}$ of seeds).

It is noteworthy that seeds with olive seed coats have the highest AOA: UD0300152 (chlorogenic acid equivalents $5.07 \mathrm{mg} \mathrm{g}^{-1}$ of seeds) and UD0300384 (4.21 $\mathrm{mg} \mathrm{g}^{-1}$ of seeds). The AOA in light-olive seeds was almost twice as little: UD0303578 (2.46 $\mathrm{mg} \mathrm{g}^{-1}$ of seeds) and UD0304013 (2.48 $\mathrm{mg} \mathrm{g}^{-1}$ of seeds). It was comparable to that in the vinous-red seeds: UD0303912 $\left(2.50 \mathrm{mg} \mathrm{g}^{-1}\right.$ of seeds) and UD03003925 (2.36 $\mathrm{mg} \mathrm{g}^{-1}$ of seeds).
The AOA in vinous-red seeds with a pink variegated pattern was higher than that in seeds with plain vinous-red colouration: UD0300286 (3.36 $\mathrm{mg} \mathrm{g}^{-1}$ of seeds) and UD0303753 (3.60 $\mathrm{mg} \mathrm{g}^{-1}$ of seeds). In seeds with pink seed coats, there was no dependence of the AOA on patterns: in plain seeds, it was $3.21 \mathrm{mg} \mathrm{g}^{-1}$ of seeds (UD0303921) and $2.82 \mathrm{mg} \mathrm{g}^{-1}$ of seeds (UD0303987); in seeds with a vinous-red variegated pattern, it was $2.72 \mathrm{mg} \mathrm{g}^{-1}$ of seeds (UD0300463).

A tendency was seen in the influence of the pattern colour and the seed coat area covered by the pattern. In the accession UD0303961 (0.82 $\mathrm{mg} \mathrm{g}^{-1}$ of seeds) with a peri-scar vinousred pattern, the AOA was similar to that in the accessions UD0303351 $\left(0.89 \mathrm{mg}^{-1}\right.$ of seeds), UD0300397 (0.82 $\mathrm{mg} \mathrm{g}^{-1}$ of seeds) and UD0300282 (0.96 $\mathrm{mg} \mathrm{g}^{-1}$ of seeds) with white seeds without a pattern. In the vinous-red accessions with a pink variegated pattern UD0303753 (3.60 $\mathrm{mg} \mathrm{g}^{-1}$ of seeds) and UD0300286 (3.36 $\mathrm{mg} \mathrm{g}^{-1}$ of seeds) covering the entire surface 
of the seed coat, this parameter was significantly higher than the values in the plain vinous-red accessions UD0303902 (2.50 $\mathrm{mg} \mathrm{g}^{-1}$ of seeds) and UD0303925 (2.36 $\mathrm{mg} \mathrm{g}^{-1}$ of seeds). However, in the isabelline accessions with a black variegated pattern UD0304011 (1.42 $\mathrm{mg} \mathrm{g}^{-1}$ of seeds) and with an olive pattern UD0300227 (2.20 $\mathrm{mg} \mathrm{g}^{-1}$ of seeds), the AOA significantly differed.

The accessions with black seed coats constituted a separate block. Their AOA significantly differed from each other: the UD0304014's (2.10 $\mathrm{mg} \mathrm{g}^{-1}$ of seeds) surface was dull, and the UD0303847's (1.54 $\mathrm{mg} \mathrm{g}^{-1}$ of seeds) surface was shiny.

Studying the AOA in seeds of the related bean species, we observed regularities in the relationship with colouration of the seed coat that were similar to those in P. vulgaris L. (Table 1).

The AOA of accessions with white seeds was the lowest in all the bean species. It was approximately at the same level in $P$. vulgaris L., $P$. lunatus L. and P. multiflorus Lam.: chlorogenic acid equivalents $=0.95-1.05 \mathrm{mg} \mathrm{g}^{-1}$ of seeds.

Table 1. AOA in seeds of the related species Phaseolus L., 2015-2017

\begin{tabular}{|c|c|c|c|}
\hline \multirow[b]{2}{*}{$\begin{array}{c}\text { Number in the National Cata- } \\
\text { logue of Ukraine }\end{array}$} & \multirow[b]{2}{*}{ Colouration of the seed coat } & \multicolumn{2}{|c|}{ Antioxidant activity } \\
\hline & & $\begin{array}{l}\text { Chlorogenic acid } \\
\text { equivalents, } \\
\text { mg g }^{-1} \text { of seeds }\end{array}$ & AOA, \% \\
\hline \multicolumn{4}{|c|}{ P. vulgaris $\mathrm{L}$. } \\
\hline UD0303351 & White & 0.95 & 14.27 \\
\hline UD0303753 & Vinous-red with a pink pattern & 4.35 & 65.05 \\
\hline \multicolumn{4}{|c|}{ P. lunatus L. } \\
\hline UD0303348 & White & 1.05 & 15.75 \\
\hline UD0303246 & White with a vinous-red pattern & 2.27 & 33.09 \\
\hline \multicolumn{4}{|c|}{ P. multiflorus Lam. } \\
\hline UD0300900 & White & 0.95 & 14.30 \\
\hline UD0303904 & White & 1.01 & 15.15 \\
\hline UD0300843 & Black with a violet pattern & 6.14 & 91.83 \\
\hline UD0300843 & Violet with a black pattern & 6.09 & 91.10 \\
\hline UD0300843 & Isabelline & 6.10 & 91.25 \\
\hline UD0300843 & Brown & 6.16 & 92.03 \\
\hline UD0300904 & White & 1.11 & 16.69 \\
\hline UD0300904 & Brown & 6.10 & 91.15 \\
\hline UD0300904 & Violet & 6.11 & 91.38 \\
\hline UD0300902 & White & 1.18 & 17.62 \\
\hline UD0300902 & Black with a violet pattern & 6.15 & 91.96 \\
\hline UD0300902 & Violet with a black pattern & 6.11 & 91.38 \\
\hline \multicolumn{4}{|c|}{ P. acutifolius A. Grey } \\
\hline UD0300204 & White & 1.27 & 19.01 \\
\hline UD0300126 & White & 1.28 & 19.16 \\
\hline UD0303771 & Brown & 1.32 & 19.77 \\
\hline UD0300133 & Brown & 1.34 & 19.96 \\
\hline UD0300130 & Ochre & 1.60 & 23.93 \\
\hline UD0300485 & Ochre & 1.62 & 24.22 \\
\hline \multicolumn{2}{|c|}{$\mathrm{LSD}_{005}$} & 0.058 & 0.871 \\
\hline
\end{tabular}


In $P$. acutifolius A. Gray, it was slightly higher (1.27-1.28 $\mathrm{mg} \mathrm{g}^{-1}$ of seeds). Pigmented seeds significantly exceeded white ones in terms of this parameter, except for P. acutifolius A. Gray, in which the difference was small: $1.32-1.34$ and $1.60-1.62 \mathrm{mg} \mathrm{g}^{-1}$ of seeds in brown and ocher seeds, respectively. In P. lunatus L., the AOA in white seeds with a vinous-red variegated pattern was more than twice as high as that in white ones without a pattern $\left(2.27 \mathrm{mg} \mathrm{g}^{-1}\right.$ of seeds). In P. multiflorus Lam., this parameter in coloured seeds was very high (6.09-6.16 $\mathrm{mg} \mathrm{g}^{-1}$ of seeds), regardless of the colour (brown, isabelline, violet, black, with or without a pattern). Moreover, segregation into groups with different colouration of the seed coat was conducted within individual accessions (UD0300843, UD0300904, UD0300902), which proves the prevailing dependence of the AOA in beans on the colouration of the seed coat.

Considering the change in AOA over the research years, it was noted that its dependence on the seed coat colour is preserved, but the dependence on the water-temperature balance of the environment is traced (Table 2).

The positive dependence of AOA on the air temperature at which seeds are formed (corre- lation coefficient is 0.82) and the negative dependence on the amount of precipitation during the growing season $(-0.98)$ are revealed. Thus, in 2017 which was characterized by severe drought (the sum of precipitation during the growing season is $15.4 \mathrm{~mm}$ ) and high temperatures (average air temperature over the vegetation period is $25.3^{\circ} \mathrm{C}$ ), AOA of bean samples regardless of the seed coat colour was higher (equivalent to chlorogenic acid $2.83 \mathrm{mg} \mathrm{g}^{-1}$ seed). The smallest AOA was in 2016 (the equivalent of chlorogenic acid was $2.20 \mathrm{mg} \mathrm{g}^{-1}$ of seed) which was characterized by an overabundance of moisture (the amount of precipitation during the growing season was $94.8 \mathrm{~mm}$ ). In 2015, the precipitation was less and the ratio of temperature and moisture approached the optimum (average air temperature during the growing season was $23.0^{\circ} \mathrm{C}$, the precipitation amount during the growing season was $66.0 \mathrm{~mm}$ ). Under these conditions, the AOA of bean samples had an intermediate value (equivalent of chlorogenic acid $2.31 \mathrm{mg} \mathrm{g}^{-1}$ seed). Our results are confirmed by Terzi et al. (2010) where it is proved that the activity of antioxidant enzymes increases due to the stress of plants as a result of drought.

Table 2. The AOA of Phaseolus vulgaris L. seeds depending on the weather conditions of the reproduction year, 2015-2017

\begin{tabular}{|c|c|c|c|c|}
\hline \multirow{2}{*}{$\begin{array}{l}\text { No. in the National Cat- } \\
\text { alogue of Ukraine }\end{array}$} & \multirow{2}{*}{ Seed coat colour } & \multicolumn{3}{|c|}{$\begin{array}{l}\text { Equivalent of chlorogenic acid, } \\
\qquad \mathrm{mg} \mathrm{g}^{-1} \text { of seed }\end{array}$} \\
\hline & & 2015 & 2016 & 2017 \\
\hline UD0303351 & White & 0.83 & 0.82 & 1.02 \\
\hline UD0303912 & Wine red & 2.25 & 2.12 & 3.04 \\
\hline UD0303753 & Wine red with a pink pattern & 3.67 & 3.23 & 3.90 \\
\hline UD0303921 & Pink & 2.98 & 3.01 & 3.62 \\
\hline UD0304012 & Isabella & 1.31 & 1.24 & 1.56 \\
\hline UD0301428 & Yellow & 1.14 & 1.50 & 1.98 \\
\hline UD0300152 & Olive & 4.75 & 4.62 & 5.85 \\
\hline UD0303616 & Brown & 1.66 & 1.40 & 1.97 \\
\hline UD0303014 & Black & 1.95 & 1.79 & 2.55 \\
\hline & Mean & 2.31 & 2.20 & 2.83 \\
\hline (least sign & int difference) $\mathrm{LSD}_{005}$ & 0.51 & 0.51 & 0.62 \\
\hline Average air tempera & over the vegetation period, ${ }^{\circ} \mathrm{C}$ & 23.0 & 24.0 & 25.3 \\
\hline Amount of precipitatic & uring the vegetation period, $\mathrm{mm}$ & 66.0 & 94.8 & 15.4 \\
\hline
\end{tabular}




\section{CONCLUSIONS}

The screening results of the NCPGRU's Phaseolus L. collection confirmed the opinion that the AOA in bean seeds depended on colouration of the seed coat. It was revealed that, regardless of beans species, the lowest antioxidant activity is shown by white seeds (chlorogenic acid equivalents 0.82$0.96 \mathrm{mg} \mathrm{g}^{-1}$ of seeds). Pigmented seeds had various AOA. In P. vulgaris L., the highest values were recorded in olive (4.21-5.07 $\mathrm{mg} \mathrm{g}^{-1}$ of seeds), vinousred (2.36-3.60 $\mathrm{mg} \mathrm{g}^{-1}$ of seeds) and pink (2.72$3.21 \mathrm{mg} \mathrm{g}^{-1}$ of seeds) seeds. A tendency was seen in the influence of the pattern colour and the seed coat area covered by the pattern. In the isabelline accession with a black variegated pattern covering the entire surface of the seed, the AOA was lower (1.42 $\mathrm{mg} \mathrm{g}^{-1}$ of seeds) than in the isabelline accession with an olive pattern (2.20 $\mathrm{mg} \mathrm{g}^{-1}$ of seeds). The accession with white seeds and a peri-scar spot (0.82 $\mathrm{mg} \mathrm{g}^{-1}$ of seeds) was comparable with the accessions with plain white seeds $(0.82,0.89$ and $0.96 \mathrm{mg} \mathrm{g}^{-1}$ of seeds). In P. lunatus L., the AOA in white seeds with a vinous-red variegated pattern (2.27 $\mathrm{mg} \mathrm{g}^{-1}$ of seeds) was more than twice as high as that in white seeds without a pattern $\left(0.94 \mathrm{mg} \mathrm{g}^{-1}\right.$ of seeds). In P. multiflorus Lam., all coloured seeds had a very high AOA, regardless of the seed coat colour and its pattern (6.09-6.16 $\mathrm{mg} \mathrm{g}^{-1}$ of seeds). In $P$. acutifolius A. Gray, this parameter changed little, depending on the colouration of the seed coat (1.27-1.62 $\mathrm{mg} \mathrm{g}^{-1}$ of seeds).

The antioxidant activity of bean seeds depends on the environmental conditions. Plant stress from drought leads to increased AOA.

Received 1 June 2018 Accepted 28 September 2018

\section{REFERENCES}

1. Arabshahi S., Urooj A. 2007. Antioxidant properties of various solvent extracts of Mulberry morusindica L. leaves. Food Chemistry. Vol. 102. P. 1233-1240.

2. Beninger C.W.2003. Antioxidant activity of extracts, condensed tannin fractions and pure flavonoids from Phaseolus vulgaris L. seed coat colour genotypes. Journal of Agricultural and Food Chemistry. Vol. 51. P. 7879-7883. Available at: https:// www.ncbi.nlm.nih.gov/pubmed/14690368

3. Bezugla O. M., Kobyzeva L. N., Ryabchun V. K., Drepin I. M., Izhik M. K., Sokol T. V., Duplyak O.
2004. Wide Unified Descriptors List of the Genus Phaseolus L. Kharkiv. 50 p. (in Ukrainian).

4. Bondarev S. V. 1954. Scale of Colors. Manual for Biologists for Research and Research-applied Investigations. Publishing House of the Academy of Sciences of the USSR. 27 p. (in Russian).

5. Bonoli M., Verardo V., Marconi E., Caboni M. F. 2004. Antioxidant phenols in barley (Hordeum vulgare L.) flour: comparative spectrophotometric study among extraction methods of free and bound phenolic compounds. Journal of Agricultural and Food Chemistry. Vol. 52. P. 5195-5200.

6. Câmara C. R. S., Urrea C. A., Schlegel V. 2013. Pinto beans (Phaseolus vulgaris L.) as a functional food: implications on human health. Agriculture. Vol. 3. P. 90-111.

7. Dospehov B. A. 1985. Methodology of Field Experiment. Moscow: Agropromizdat. 351 p. (in Russian).

8. Duan X.-J., Zhang W.-W., Li X.-M., Wang B.-G. 2006. Evaluation of antioxidant property of extract and fractions obtained from a red alga, Polysiphonia urceolata. Food Chemistry. Vol. 95(1). P. 37-43.

9. Hajimahmoodi M., Sadeghi N., Jannat B., Oveisi M. R., Madani S., Kiayi M., Akrami M. R., Ranjbar A. M. 2008. Antioxidant activity, reducing power and total phenolic content of Iranian olive cultivar. Journal of Biological Sciences. Vol. 8(4). P. 779-783. Available at: https://scialert.net/ abstract/?doi=jbs.2008.779.783

10. Jenkins D. J. A., Kendall C. W. C., Jackson C.-J. C., Connelly P. W., Parker T., Faulkner D., Vidqen E., Cunnane S. C., Leinter L. A., Josse R. G. 2002. Effects of high- and low-isoflavone soyfoods on blood lipids, oxidized LDL, homocysteine, and blood pressure in hyperlipidemic men and women. The American Journal of Clinical Nutrition. Vol. 76(2). P. 365-372. Available at: https://www. ncbi.nlm.nih.gov/pubmed/12145008

11. Kobyzeva L. N., Bezugla O. M., Sylenko S. I., Kolotilov V. V., Sokol T. V., Dokukina K. I., Vasylenko A. O., Bezuglyi I. M., Vus N. O. 2016. Methodical Recommendations on the Study of Leguminous Crops Genetic Resources. Kharkiv. 84 p. (in Ukrainian).

12. Lin J.-Y., Tang C.-Y. 2007. Determination of total phenolic and flavonoid contents in selected fruits and vegetables, as well as their stimulatory effects on mouse splenocyte proliferation. Food Chemistry. Vol. 101(1). P. 140-147.

13. Maina A. N., Yanou N. N., Tchiagam J.-B. N., Nguimbou R. M., Bell J. M. 2005. Inheritance of antioxidant activity and its association with seedcoat color in cowpea. Journal of the American Society for Horticultural Science. Vol. 130(3). Available at: https://www.researchgate.net/publication/277837222 Inheritance_of_Antioxidant_Activity_and_its_ Association_with_Seedcoat_Colour_in_Cowpea 
14. Marathe S. A., Rajalakshmi V., Jamdar S. N., Sharma A. 2011. Comparative study on antioxidant activity of different varieties of commonly consumed legumes in India. Food and Chemical Toxicology. Vol. 49(9). P. 2005-2012. Available at: https://www.sciencedirect.com/science/article/pii/ S0278691511002006

15. Nijveldt R. J., van Nood E., van Hoorn D. E. C., Boelens P. G., van Norren K., van Leeuwen P. A. 2001. Flavonoids: a review of probable mechanisms of action and potential applications. The American Journal of Clinical Nutrition. Vol. 74(4). P. 418-425.

16. Nyau V., Prakash S., Rodrigues J., Farrant J. 2016. Screening different Zambian market classes of common beans (Phaseolus vulgaris) for antioxidant properties and total phenolic profiles. Journal of Food and Nutrition Research. Vol. 4(4). P. 230-236.

17. Onyeneho S. N., Hettiarachchy N. S. 1991. Effect of navy bean hull extract on the oxidative stability of soy and sunflower oils. Journal of Agricultural and Food Chemistry. Vol. 39. P. 1701-1704.

18. Oomah B. D., Corbé A. L., Balasubramanian P. 2010. Antioxidant and antiinflammatory activities of bean (Phaseolus vulgaris L.) hulls. Journal of Agricultural and Food Chemistry. Vol. 58. P. 8225-8230.

19. Pourmorad F., Hosseinimehr S. J., Shahabimajd N. 2006. Antioxidant activity, phenol and flavonoid contents of some selected Iranian medicinal plants. African Journal of Biotechnology. Vol. 5(11). P. 11421145. Available at: https://www.academicjournals. org/article/article1379770522_Pourmorad\%20 et $\% 20$ al.pdf

20. Pozdnyakov V. V., Vasylenko A. O. 2017. Use of test systems for assessing the total antioxidant activity in seeds. Selektchiya i Nasinnytchtvo. Vol. 112. P. 153163 (in Russian).

21. Selyaninov G. G. 1930. To the question of classification of agricultural crops by climatic trait. Trudy po selskohozyaystvennoy meteorologii. Vol. 21(2). P. 224 (in Russian).

22. Terzi R., Sağlam A., Kutlu N., Nar H., Kadioğlu A. 2010. Impact of soil drought stress on photochemical efficiency of photosystem II and antioxidant enzyme activities of Phaseolus vulgaris cultivars. Turkish Journal of Botany. Vol. 34. P. 1-10. Available at: https://www.researchgate. net/publication/278080323_Impact_of_soil_ drought_stress_on_photochemical_efficiency_of_ photosystem_II_and_antioxidant_enzyme_activities_of_Phaseolus_vulgaris_cultivars

23. Tsuda T., Osawa T., Nakayama S., Awakishi S., Ohshima K. 1993. Antioxidant activity of pea bean (Phaseolus vulgaris L.) extract. Journal of the American Oil Chemists' Society. Vol. 70. P. 910-913.
24. Yashin A. Y., Chernousova N. I. 2009. Natural Antioxidants. Contents in Foods and Their Effects on Human Health and Aging. TransLit. 212 p. (in Russian).

25. Zhou K., Yu L. 2004. Effects of extraction solvent on wheat bran antioxidant activity estimation. Lebensmittel-Wissenschaft und -Technologie. Vol. 37. P. 717-721.

\author{
O. N. Bezuhla, V. V. Pozdniakov, L. N. Kobyzeva, \\ R. L. Boguslavskiy, O. V. Antsyferova
}

\section{PHASEOLUS L. GENTIES AUGALŲ RŪŠIŲ SĖKLŲ SU SKIRTINGOS SPALVOS LUOBELE ANTIOKSIDACINIS AKTYVUMAS}

Tyrimo tikslas - ištirti skirtingų pupelių rūšių sẻklų, besiskiriančių luobelès spalva, antioksidacini aktyvumą. Tirtos Ukrainos nacionalinio augalų genetinių išteklių centro kolekcijoje saugomų rūšių Phaseolus vulgaris L., P. multiflorus Lam., P. lunatus L., P. acutifolius A. Grey sèklos. Antioksidanto aktyvumas buvo nustatytas naudojant DPPH pagalba patobulintą stabilių radikalų surišimo metodą. Metilo alkoholis tirpale buvo pakeistas netoksišku etilo alkoholiu. Analizès rezultatai pateikiami kaip standartinio antioksidanto (chlorogeno rūgšties) ekvivalentas, išreiškiamas mg standarto $1 \mathrm{~g}$ mėginio, atsižvelgiant i skiedimus pagal kalibravimo grafiką. Nustatyta, kad pupelių sèklų antioksidacinis aktyvumas priklauso nuo sèklų luobelès spalvos. Nepriklausomai nuo pupelių rūšies, mažiausias rodiklis buvo stebètas baltose sèklose (ekvivalentas chlorogeno rūgščiai $0,82-0,96 \mathrm{mg} \mathrm{g}^{-1}$ sèklos). Spalvotos pupelès turèjo ịvairų antioksidacinị aktyvumą. $P$. vulgaris L. rūšyje aukščiausias antioksidacinio aktyvumo rodiklis nustatytas alyvuogių spalvos pupelèse (4,21-5,07 $\mathrm{mg} \mathrm{g}^{-1}$ sèklų), raudonojo vyno spalvos $\left(2,36-3,60 \mathrm{mg} \mathrm{g}^{-1}\right.$ sèklų) ir rožinèse $\left(2,72-3,21 \mathrm{mg} \mathrm{g}^{-1}\right.$ sèklų) . Taip pat pastebèta sèklų piešinio ir spalvotos zonos ploto ittaka antioksidaciniam aktyvumui. $P$. lunatus L. baltų sèklų su ryškiu vynuogių raudonumo raštu antioksidacinis aktyvumas $\left(2,27 \mathrm{mg} \mathrm{g}^{-1}\right.$ sèklų) buvo daugiau nei dvigubai didesnis, palyginti su baltų sèklų $(0,94$ $\mathrm{mg} \mathrm{g}^{-1}$ sèklos) P. multiflorus Lam. Visos spalvotos sèklos turèjo labai didelį antioksidacinį aktyvumą, nepriklausomai nuo sèklos spalvos ir raštuotumo (6,09-6,16 $\mathrm{mg} \mathrm{g}^{-1}$ sèklų). P. acutifolius A. Grey šio parametro pokytis dẻl sẻklų spalvos buvo mažas (1,27-1,62 mg g ${ }^{-1}$ sèklų). Nustatyta, kad pupelių antioksidacinis aktyvumas priklauso nuo aplinkos sąlygų, ypač streso, kurị sukelia sausra.

Raktažodžiai: antioksidacinis aktyvumas, Phaseolus vulgaris L., Phaseolus multiflorus Lam., Phaseolus lunatus L., Phaseolus acutifolius A.Grey, sèklų luobelès spalva 